\title{
O.S.P.
}

\section{6/1 - La question de l'expertise dans le conseil en orientation avec les personnes handicapées}

Joëlle Mezza

\section{OpenEdition}

1 Journals

Édition électronique

URL : http://journals.openedition.org/osp/9695

DOI : 10.4000/osp.9695

ISSN : 2104-3795

Éditeur

Institut national d'étude du travail et d'orientation professionnelle (INETOP)

Édition imprimée

Date de publication : 1 décembre 2018

Pagination : 730-731

ISSN : 0249-6739

\section{Référence électronique}

Joëlle Mezza, «36/1 - La question de l'expertise dans le conseil en orientation avec les personnes handicapées », L'orientation scolaire et professionnelle [En ligne], 47/4 | 2018, mis en ligne le 01 décembre 2020, consulté le 18 décembre 2020. URL : http://journals.openedition.org/osp/9695; DOI : https://doi.org/10.4000/osp.9695

Ce document a été généré automatiquement le 18 décembre 2020.

(c) Tous droits réservés 


\section{6/1 - La question de l'expertise dans le conseil en orientation avec les personnes handicapées}

Joëlle Mezza

\section{RÉSUMÉS}

Existe-t-il des activités spécifiques de conseil en orientation avec un public de personnes handicapées? Une observation des pratiques développées par les conseillers d'orientation psychologues du CIO de Paris spécialisé dans l'accompagnement de ces publics met en évidence qu'une demande récurrente leur est adressée : celle d'être des experts utilisant des tests. Par ailleurs, la particularité (et aussi la difficulté) de la situation de certaines personnes handicapées conduit les conseillers d'orientation psychologues du CIO spécialisé à devoir réfléchir collectivement - sans doute plus fréquemment que les autres conseillers - sur leurs pratiques, sur les outils dont ils disposent, sur les usages qu'ils en font et sur le cas des personnes qu'ils rencontrent, etc. On peut postuler que l'engagement dans de telles réflexions et analyses se traduit à la fois par un enrichissement et une certaine homogénéisation de leurs méthodologies. La finalité de leurs pratiques apparaît néanmoins identique à celles destinées au public tout venant : accompagner les jeunes (et les adultes) dans leur construction de soi, notamment en les aidant à formuler des projets de vie (des projets personnels, de formation, professionnels) et en s'engageant activement dans leur réalisation.

\section{INDEX}

Mots-clés : accompagnement, conseil en orientation, expertise, personne handicapée, test 